\title{
Association of TIMP-1 and COL4A4 Gene Polymorphisms with Keratoconus in an Iranian Population
}

\author{
Davood Yari ${ }^{1,2,3}$, PhD; Zohreh Ehsanbakhsh ${ }^{3,4}$, BS; Mohammad-Hosein Validad ${ }^{5}$, MD \\ Farzaneh Hasanian Langroudi ${ }^{2}$, PhD \\ ${ }^{1}$ Cellular and Molecular Research Center, Zahedan University of Medical Sciences, Zahedan, Iran \\ ${ }^{2}$ Department of Clinical Biochemistry, School of Medicine, Zahedan University of Medical Sciences, Zahedan, Iran \\ ${ }^{3}$ Mashhad University of Medical Sciences, Mashhad, Iran \\ ${ }^{4}$ Shariati Hospital, Mashhad University of Medical Sciences, Mashhad, Iran \\ ${ }^{5}$ Department of Ophthalmology, Alzahra Eye Hospital, Zahedan University of Medical Sciences, Zahedan, Iran
}

ORCID:

Davood Yari: https://orcid.org/0000-0001-6105-4326

\section{Abstract}

Purpose: Keratoconus $(\mathrm{KC})$ is a bilateral and noninflammatory disease, characterized by progressive thinning and anterior protrusion of the cornea and may result in severe visual impairment due to irregular astigmatism. Matrix metalloproteinases (MMP) are the main group of enzymes that degrade extracellular matrix proteins including collagens; Type IV collagen is found in the corneal stroma. MMP enzymatic activity is inhibited by tissue inhibitor of metalloproteinase-1 (TIMP-1). A decrease in TIMP-1 level is associated with the development of KC. In the present study, we investigated the impact of COL4A4 rs $2228557 \mathrm{C} / \mathrm{T}$ and TIMP-1 rs4898 C/T (X-chromosome) variants on the odds of $\mathrm{KC}$ development in a sample of Iranian population.

Methods: This case-control study was conducted on 140 patients with $\mathrm{KC}$ and 150 healthy control subjects. We used modified methods of Nested-PCR and ARMS-PCR in combination (NestedARMS-PCR) and confirmed their validity with RFLP-PCR.

Results: Significant differences were noticed between KC patients and healthy individuals regarding the genotype TY or T allele frequencies of rs4898 in the male subjects $(O R=0.43$, $95 \% \mathrm{Cl}$ : 0.20-0.92, $P=0.03$ ), whereas no significant differences were identified in the female subjects (OR $=1.07,95 \% \mathrm{Cl}: 0.52-2.20, P=0.85)$. The rs2228557, T allele was associated with $\mathrm{KC}(\mathrm{OR}=0.69,95 \% \mathrm{Cl}: 0.50-0.97, P=0.035)$.

Conclusion: In the rs2228557 variant, T allele acts as a protective factor from the disease and decreases the risk of $\mathrm{KC}$ compared with the $\mathrm{C}$ allele. Also, in our investigation about rs4898, we found that TY genotype or T allele decreased the risk of $\mathrm{KC}$ compared with the $\mathrm{C}$ allele in males and was a protective factor for $\mathrm{KC}$ in our population.

Keywords: Collagen; COL4A4; Keratoconus; Polymorphism; TIMP-1

J Ophthalmic Vis Res 2020; 15 (3): 299-307

\section{Correspondence to:}

Davood Yari, PhD. Cellular and Molecular Research Center, Zahedan University of Medical Sciences, Zahedan 98167, Iran.

Email: Davidyari.85@gmail.com

Received: 01-03-2019 Accepted: 14-03-2020

\section{Access this article online}

Website: https://knepublishing.com/index.php/JOVR

DOI: 10.18502/jovr.v15i3.7448

\section{INTRODUCTION}

Keratoconus $(\mathrm{KC})$ is defined as a bilateral, non-inflammatory, and progressive disease

This is an open access journal, and articles are distributed under the terms of the Creative Commons Attribution-NonCommercial-ShareAlike 4.0 License, which allows others to remix, tweak, and build upon the work non-commercially, as long as appropriate credit is given and the new creations are licensed under the identical terms.

How to cite this article: Yari D, Ehsanbakhsh Z, Validad M-H, Langroudi FH. Association of TIMP-1 and COL4A4 Gene Polymorphisms with Keratoconus

in an Iranian Population. J Ophthalmic Vis Res 2020;15:299-307. 
characterized by conical protrusion of the cornea. This disease may result in severe visual impairment due to irregular astigmatism and stromal scarring. $\mathrm{KC}$ eventually affects both eyes, although the involvement is usually asymmetric. The symptoms of KC-affected patients are different depending on the stage of the disease. ${ }^{[1-3]}$ Glasses or contact lenses can provide useful vision in the early stage of the disease; nonetheless, corneal transplantation is mandatory for visual rehabilitation in $20 \%$ of the patients who are in advanced stage. Corneal thinning is considered as one of the identifying characteristics of KC. Central corneal thickness (CCT) is lower in KC patients by $75 \mu \mathrm{m}$ as compared to normal controls. ${ }^{[4,5]}$

The incidence of $\mathrm{KC}$ is approximately 1 per 2,000 , and its prevalence is 54.5 per 100,000 . This disease occurs in both genders, ${ }^{[6]}$ with different rates among different ethnic groups. ${ }^{[7]} \mathrm{KC}$ usually begins in teens, and its progression slows after the age of 30 years. ${ }^{[6]}$

$\mathrm{KC}$ is a multi-factorial disorder; environmental factors cause $K C$ in genetically susceptible individuals. The environmental factors that may play roles in the pathogenesis of $\mathrm{KC}$ include eye rubbing, allergy, connective tissue dysfunction, and contact lens wear. Moreover, subjects with a family history of $\mathrm{KC}$ are more susceptible to this disorder. ${ }^{[8]}$ Using family-based linkage, several case-control studies have determined various genes that increase the odds of KC development. ${ }^{[9]}$ The gene candidates for $K C$ include $L O X,{ }^{[10]}$ VSX1, ${ }^{[11]} \quad G P X-1,{ }^{[12]} \quad T G F-\beta 1,{ }^{[13]} \quad C O L 4 A 3$ and COL4A4 ${ }^{[14]}$ (polymorphism or mutation), and TIMP1, ${ }^{[15]} M M P-2, M M P-9^{[16]}$ (gene expression). $\mathrm{KC}$ is still an enigmatic disease in many aspects, including inheritance, basic pathophysiology, prevention, associated risk factors, disease development, as well as therapeutic approaches. ${ }^{[17]}$

Type IV collagen is only present in basement membranes and constitutes their main structural component. Collagen type IV gene, alpha-4 (COL4A4), is located in the region $2 q 35-q 37$ with a gene span composed of $113 \mathrm{~kb}$ and 48 exons. ${ }^{[18,19]}$ Type IV collagen is not expressed in cornea in the normal condition and its presence indicates a corneal pathology; therefore, type IV collagen can be a potential candidate in the pathogenesis of KC. In support of this theory, alterations in the expression level of collagen type IV ( $\alpha-4$ chains) were observed in corneas inflicted by $\mathrm{KC}$. ${ }^{[2,21]}$ Matrix metalloproteinases (MMP) are the major expressed metalloproteases in the cornea. It has been demonstrated that the proteolytic activity of MMP increases in KC. This finding suggests that abnormal MMP activity plays a role in the pathogenesis of $\mathrm{KC} .{ }^{[16,22]}$

Four types of tissue inhibitor of metalloproteinase (TIMP1-4) have been detected; three of which, including TIMPs-1, 3, and 4, are nested within an intron in the genes of synapsins. TIMP inhibits collagenases and proteoglycanase called matrix metalloproteinase. All four types of TIMPs have various biological activities apart from their metalloproteinase inhibitory activity. These biological activities include the promotion of cell proliferation, cancer promotion, regulation of angiogenesis, as well as pro- and anti-apoptotic and synaptic flexibility activities, many of which are independent of metalloprotease inhibition. TIMP-1 is associated with synapsin 1 and its gene is located in X11p11.23-11.4 consisting of six exons. Mature TIMP-1 is a $28.5 \mathrm{kDa}$ glycoprotein that consists of 184 amino acid residues. The natural precursor contains a signal peptide of 23 residues which are cleaved throughout the protein maturation. ${ }^{[23-27]}$ TIMP-1 suppresses angiogenesis and controls the balance in the corneal tissue by inhibiting the action of matrix metalloproteinase to protect tissues from permanent damage. ${ }^{[28]}$ Furthermore, it has been demonstrated that increased MMP and decreased TIMP levels are associated with the development of KC. ${ }^{[29]}$

COL4A4 gene rs2228557 (F1644F) (HGVM1660028) is located in chromosome 2 exon 48, NM_000092.4 region. Several studies examined the association between COL4A4 and $\mathrm{KC}$ and revealed that this gene is associated with $\mathrm{KC}$; however, some other studies failed to find the same relationship in different populations. ${ }^{[14,22,30,31]}$

TIMP-1 gene rs4898 (+372C/T) (HGVM6380940) is located within the intron of the synapsin gene, and single nucleotide polymorphism (SNP) is located in exon 5, the region of NM_006950.3. Some studies investigated the association of rs4898 gene polymorphism with disorders including intracerebral hemorrhage, ${ }^{[32]}$ systemic sclerosis, ${ }^{[33]}$ and severe sepsis. ${ }^{[34]}$

The present study aimed to evaluate the possible association of TIMP-1 rs4898 C/T gene polymorphism and COL4A4 rs2228557 C/T gene 
polymorphism with the development of $\mathrm{KC}$ in a sample of Iranian population.

\section{METHODS}

\section{Patients}

The current retrospective case-control study was conducted at the Alzahra Eye Hospital, Zahedan University of Medical Sciences, Zahedan, Iran and recruited 140 unrelated Iranian patients with KC and 150 unrelated healthy controls. The patients were diagnosed with $\mathrm{KC}$ after a comprehensive ophthalmic examination using the following criteria: (1) clinical signs of KC (Munson sign, protrusion, Vogts striae, corneal thickness, scarring, Fleischer ring) and abnormal findings in corneal topography (Pentacam AXL, OCULUS INC); (2) the three quantitative videokeratographic indices used for the screening of $\mathrm{KC}$ were central corneal power $>47.2 \mathrm{D}$, inferior-superior value $>$ 1.4 D, Sim-K astigmatism > 1.5 D, and skewed radial axes $>21^{\circ} .{ }^{10,35]}$ Patients with other ocular diseases were excluded from the study. Controls were sexand age-matched healthy participants who were unrelated to the patients and were selected from a geographic area similar to that of KC subjects.

The Ethics Committee of Zahedan University of Medical Sciences, Zahedan, Iran approved the study protocol and informed consent was signed by all participants. This study complied with the tenets of the Declaration of Helsinki.

\section{Analysis of the TIMP-1 (rs4898), COL4A4 (rs2228557) Polymorphisms}

Blood samples were collected in EDTA-containing tubes and genomic DNA was extracted from the peripheral blood leukocytes using salting out method as previously described. ${ }^{[36]}$ All procedures were performed under a standardized setting to avoid variation in DNA quality. SNP rs2228557 COL4A4 was evaluated by ARMS-PCR. For the detection of rs4898 TIMP-1, we used the combination of Nested-polymerase chain reaction (Nested-PCR) ${ }^{[37]}$ and amplification refractory mutation system-PCR(ARMS-PCR) ${ }^{[38]}$ (NestedARMS-PCR). The verification of these methods was accomplished using Restriction Fragment Length Polymorphism (RFLP-PCR). ${ }^{[39]}$
The rs4898 location was very challengeable for ARMS-PCR; therefore, for the detection of the SNP, we used Nested or hemi-Nested-PCR primers, as mentioned previously. ${ }^{[40]}$ The advantages of this modification include elimination of non-specific products, protection of SNP position for the next steps, low cost, and short duration of the process.

PCR reactions were performed using PCR master mix (Ampliqon Taq 2x mastermix, Denmark) according to the manufacturer's instructions. For investigation of COL4A4 (rs2228557), amplification reaction was provided in $20 \mu \mathrm{L}$ volume including: 1 $\mu \mathrm{L}$ template DNA ( 100 ng/ $\mu \mathrm{L}), 1 \mu \mathrm{L}$ of each primer (10 pmol/ $/ \mathrm{L}), 10 \mu \mathrm{L}$ mastermix, and $7 \mu \mathrm{L}$ DNase-free water. The PCR conditions were set as follow: $95^{\circ} \mathrm{C}$ for $5 \mathrm{~min}, 30$ cycles of $95^{\circ} \mathrm{C}$ for $30 \mathrm{sec}, 55^{\circ} \mathrm{C}$ for $35 \mathrm{sec}, 72^{\circ} \mathrm{C}$ for $30 \mathrm{sec}$, and a final extension at $72^{\circ} \mathrm{C}$ for $5 \mathrm{~min}$. PCR products were detected by electrophoresis on a $2 \%$ agarose gel staining by ethidium bromide (Figure 1A).

In the first stage of study for TIMP-1 rs4898, Nested-PCR reaction was performed in $20 \mu \mathrm{L}$ volume including: $1 \mu \mathrm{L}$ template DNA ( 100 $\mathrm{ng} / \mu \mathrm{L})$, $1 \mu \mathrm{L}$ of each primer (10 pmol/ $\mu \mathrm{L}), 10 \mu \mathrm{L}$ mastermix, and $7 \mu \mathrm{L}$ DNase-free water. The PCR conditions were set as follow: $95^{\circ} \mathrm{C}$ for $5 \mathrm{~min}, 30$ cycles of $95^{\circ} \mathrm{C}$ for $30 \mathrm{sec}, 64^{\circ} \mathrm{C}$ for $40 \mathrm{sec}, 72^{\circ} \mathrm{C}$ for $30 \mathrm{sec}$, and a final extension at $72^{\circ} \mathrm{C}$ for $5 \mathrm{~min}$. In the second phase, the PCR product obtained from the first stage (660 bp) was used as the template and diluted 1:50. Primers for ARMS-PCR were designed to detect the SNP (Table 1). In this step, ARMS-PCR reaction was performed in $20 \mu \mathrm{L}$ volume including: $1 \mu \mathrm{L}$ template (1:50 dilution), $1 \mu \mathrm{L}$ of each primer (10 $\mathrm{pmol} / \mathrm{\mu L}), 10 \mu \mathrm{L}$ mastermix, and $7 \mu \mathrm{L}$ DNase-free water. The PCR conditions were set as follow: $95^{\circ} \mathrm{C}$ for $5 \mathrm{~min}, 17 \mathrm{cycles}$ of $95^{\circ} \mathrm{C}$ for $30 \mathrm{sec}, 56^{\circ} \mathrm{C}$ for $30 \mathrm{sec}, 72^{\circ} \mathrm{C}$ for $30 \mathrm{sec}$, and a final extension at $72^{\circ} \mathrm{C}$ for $5 \mathrm{~min}$. PCR products were detected by electrophoresis on a $2 \%$ agarose gel staining by ethidium bromide (202bp product). Consequently, SNP (rs4898) TIMP-1 was successfully detected with the combination of two methods (Nested-PCR and ARMS-PCR) (Figures B1 \& B2).

RFLP-PCR was applied to validate the method and results of screening of rs4898 polymorphism in TIMP-1. As the original sequence of the region surrounding the polymorphism does not make a restriction enzyme site, a site-directed mutagenesis PCR primer $\left(R^{*}\right)$ was designed. This primer differs from the referent sequence in two 

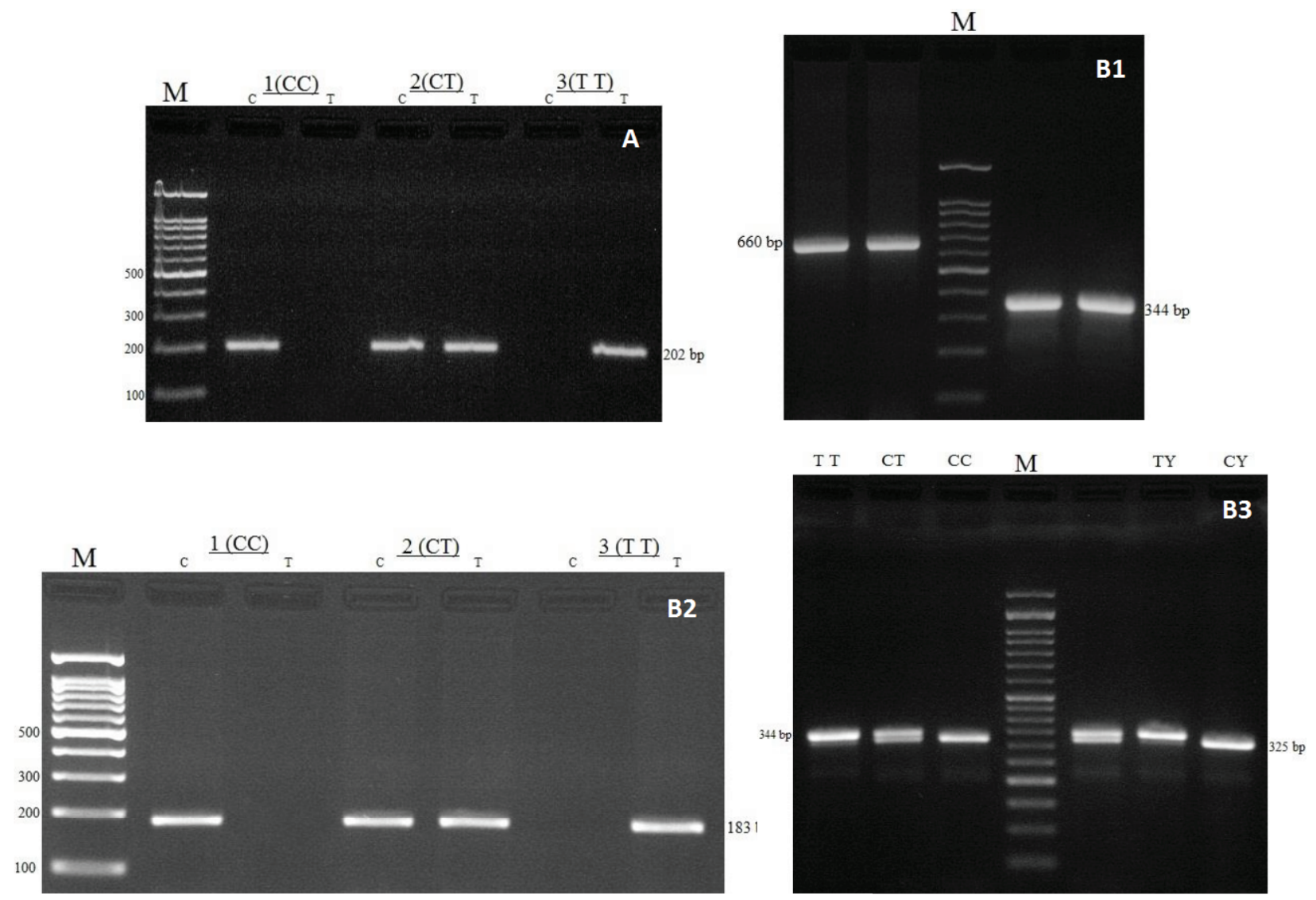

Figure 1. Electrophoresis pattern for the detection of SNPs in COL4A4 rs2228557 and TIMP-1 rs4898.

(A) Arms-PCR products of COL4A4 rs2228557, M: DNA marker (100 bp). (B1) TIMP-1 rs4898, Nested-PCR products, M: DNA marker (100bp), product size (660 and 344bp), respectively. (B2) ARMS-PCR products, product size (202bp), (TT, TC, CC) demonstrate genotypes. (B3) RFLP-PCR products, M: DNA marker (50bp), product sizes were 344bp for TT, 344bp and 325bp for TC, 325bp for CC in female, 344bp for TY and 325bp for CY in male, (TT, TC, CC) demonstrate female and (TT = TY, CC $=\mathrm{CY})$ demonstrate male genotypes, ( $\mathrm{Y}$ stands for the $\mathrm{Y}$-chromosome).

Table 1. The list of primers and methods used for detection of Single Nucleotide Polymorphisms (SNPS) TIMP-1 rs4898 and COL4A4 rs2228557

\begin{tabular}{|c|c|c|c|}
\hline TIMP-1(rs4898) T/C & & Primers(5'-3') & Product size \\
\hline \multirow{3}{*}{ Stage 1Nested-PCR } & $\mathrm{F}$ & TGGGGACACCAGAAGTCAAC & \multirow[t]{2}{*}{$660 \mathrm{bp}$} \\
\hline & $\mathrm{R}$ & TAAGCTCAGGCTGTTCCAGG & \\
\hline & F Common & AGGCTCTGATGAGAATGGTCCCA & \multirow{3}{*}{$202 \mathrm{bp}$} \\
\hline \multirow[t]{2}{*}{ Stage 2ARMS-PCR } & R (C allele) & CAGATTGTTCCAGGGAGCCAAG & \\
\hline & $\mathrm{R}$ (T allele) & CAGATTGTTCCAGGGAGCCAAA & \\
\hline \multirow[t]{2}{*}{ Stage 3RFLP-PCR } & $\mathrm{F}$ & CCGCCATGGAGAGTGTCTGC & \multirow[t]{2}{*}{$344 \mathrm{bp}$} \\
\hline & $\mathrm{R}^{*}$ & AGGCTGTTCCAGGGAGTCGC & \\
\hline \multicolumn{4}{|c|}{ COL4A4(rs2228557) C/T } \\
\hline \multirow{3}{*}{ ARMS-PCR } & F Common & TGTCTGAGCCCTAATTCTCT & \multirow{3}{*}{$183 \mathrm{bp}$} \\
\hline & $\mathrm{R}$ (C allele) & GAGCCAGAAGCTATACTTATTTGAG & \\
\hline & $\mathrm{R}$ (T allele) & GAGCCAGAAGCTATACTTATTTGAA & \\
\hline
\end{tabular}

F, forward; $R$, reverse; $R^{*}$, altered reverse 
Table 2. Genotype and allelic frequencies of COL4A4 rs2228557 and TIMP-1 rs4898 polymorphisms between keratoconus (KC) patients and healthy controls

\begin{tabular}{|c|c|c|c|c|}
\hline Variants & KC Patients n (\%) & Controls n (\%) & *OR (95\% Cl) & P-value \\
\hline \multicolumn{5}{|c|}{ rs2228557,COL4A4 } \\
\hline CC & $67(47.8)$ & $61(40.7)$ & Ref. & - \\
\hline CT & 39 (27.9) & $37(24.7)$ & $0.96(0.54-1.69)$ & 0.887 \\
\hline TT & $34(24.3)$ & $52(34.6)$ & 0.59 (0.34-1.03) & 0.067 \\
\hline \multicolumn{5}{|l|}{ Allele } \\
\hline C & $173(61.8)$ & $159(53)$ & Ref. & - \\
\hline $\mathbf{T}$ & $107(38.2)$ & $141(47)$ & $0.69(0.50-0.97)$ & 0.035 \\
\hline rs4898,TIMP-1 & Male & Male & & \\
\hline CY & $46(75.4)$ & $37(57)$ & Ref. & - \\
\hline \multirow[t]{2}{*}{ TY } & $15(24.6)$ & $28(43)$ & $0.43(0.20-0.92)$ & 0.038 \\
\hline & Female & Female & & \\
\hline CC & $28(47.5)$ & $31(52.5)$ & Ref. & - \\
\hline CT & $29(49.2)$ & $30(50.8)$ & $1.01(0.46-2.19)$ & 0.97 \\
\hline TT & $22(47.8)$ & $24(52.2)$ & $1.07(0.52-2.20)$ & 0.854 \\
\hline \multicolumn{5}{|l|}{ Allele } \\
\hline C & $85(53.8)$ & $92(54.1)$ & Ref. & - \\
\hline $\mathbf{T}$ & $73(46.2)$ & $78(45.9)$ & $1.01(0.66-1.56)$ & 0.953 \\
\hline
\end{tabular}

Ref., reference; OR, odds ratio; $\mathrm{Cl}$, confidence interval; $\mathrm{n}$, number *Adjusted for sex and age. (Y states for the $\mathrm{Y}$-chromosome)

Table 3. Correlation of clinical and keratometric parameters with COL4A4 (rs2228557) and TIMP-1(rs4898) in keratoconus patients.

\begin{tabular}{|c|c|c|c|c|c|}
\hline $\begin{array}{l}\text { Parameters } \\
\text { evaluated }\end{array}$ & Patients n (\%) & rs2228557 & P-value & rs4898 & P-value \\
\hline & & & & Male & Female \\
\hline
\end{tabular}

\section{KC ocular}

$\begin{array}{llll}\text { OD } & 42(30.0) & 0.25 & 0.39 \\ \text { OS } & 36(25.7) & & 0.4 \\ \text { OU } & 62(44.3) & & 0.014 \\ \text { Level of KC } & & & \\ \text { KK 1 } & 33(23.6) & 0.81 & 0.97 \\ \text { KK 2 } & 45(32.1) & & \\ \text { KK 3 } & 62(44.3) & & 0.71 \\ \text { CXL } & 39(27.9) & & 0.37 \\ \text { OD } & 40(28.6) & 0.58 & \\ \text { OS } & 42(30.0) & & \\ \text { OU } & 19(13.6) & & \end{array}$

Correlation of clinical and keratometric parameters with COL4A4 (rs2228557) and TIMP-1 (rs4898) in keratoconus patients. $\mathrm{KC}$, keratoconus; OD, right eye; OS, left eye; OU, both eyes; $\mathrm{CXL}$, cross-linking surgery

KK1, 2, 3 are phenotyping classification and show the level progress of keratoconus disease in patients 
bases and lies close to the polymorphic spot to alter the sequence and provide a restriction enzyme site at product. Thus, the original sequence of the region is TT(C) GTGG, while our PCR product was in fact TT(C) GCGA. The $\mathrm{C}$-variant is a palindrome which forms a site for the Bsp68I (Nrul) restriction enzyme (Thermo scientific). ${ }^{[40]}$

Initially, we amplified $\mathrm{PCR}$ product (660bp) using the abovementioned conditions. For alteration in the restriction enzyme site, secondary primers were added to template 1:50 dilution of first stage using the following condition: $1 \mu \mathrm{L}$ template $11: 50$ dilution), $1 \mu \mathrm{L}$ of each primer (10 pmol/ $\mathrm{LL}$ ), 10 $\mu \mathrm{L}$ mastermix, and $7 \mu \mathrm{L}$ DNase-free water. The PCR conditions were set as follow: $95^{\circ} \mathrm{C}$ for 5 min, 30 cycles of $95^{\circ} \mathrm{C}$ for $30 \mathrm{sec}, 63^{\circ} \mathrm{C}$ for 30 $\mathrm{sec}, 72^{\circ} \mathrm{C}$ for $30 \mathrm{sec}$, and a final extension at $72^{\circ} \mathrm{C}$ for $5 \mathrm{~min}$. PCR products were detected by electrophoresis on a $2 \%$ agarose gel with ethidium bromide (344bp product). For optimal results, PCR products were digested at $37^{\circ} \mathrm{C}$ for $5 \mathrm{~h}$ according to the manufacturer's instruction. The restriction of the C-allele PCR product resulted in 325bp and 19bp digest products, whereas the $\mathrm{T}$ allele (wild type) products remained unrestricted (Figure B3).

\section{Statistical analysis}

Statistical analyses were performed using the SPSS software version 19.0 (SPSS Inc., Chicago IL, USA). Frequencies were compared between the study groups using the Chi-square test. Association of gene polymorphisms with $\mathrm{KC}$ was investigated and compared between the groups using logistic regression analysis, estimation of odds ratio (OR), and 95\% confidence intervals $(\mathrm{Cl})$, respectively. A $p$-value $<0.05$ was regarded as statistically significant.

\section{RESULTS}

A total of 140 patients (61 male and 79 female subjects), aged $28 \pm 12.5$ years, included the KC group. The control group consisted of 150 healthy controls (65 male and 85 female subjects), aged $29.8 \pm 15.6$ years.

There was no significant difference between the two groups regarding the age and gender $(P=$ 0.20).
The Col4A4 rs2228557 C/T variant, $\mathrm{T}$ allele was associated with a decrease in the risk of $\mathrm{KC}$ development $(\mathrm{OR}=0.69,95 \% \mathrm{Cl}$ : 0.50-0.97, $P$ $=0.035)$, as compared to $C$ allele. Our results indicated that TT was not associated with $\mathrm{KC}$ as compared to CC (OR $=0.59,95 \% \mathrm{Cl}=0.34-1.03$, $P=0.067$ ) (Table 2).

Table 2 demonstrates the genotype and allelic frequencies of TIMP-1 (rs4898) gene polymorphism in each study group. Since TIMP-1 is an X-linked gene, the results were compared in male and female subjects separately. This analysis demonstrated that TY genotype or $\mathrm{T}$ allele decreased the risk of $\mathrm{KC}$ in male subjects as compared to the $\mathrm{C}$ allele $(\mathrm{OR}=0.43,95 \% \mathrm{Cl}$ : $0.20-0.92, P=0.03)$. However, no significant association was found between TT genotype (OR $=1.07,95 \% \mathrm{Cl}: 0.52-2.20, P=0.854)$ or $\mathrm{T}$ allele (OR $=1.01,95 \% \mathrm{Cl}: 0.66-1.56, P=0.95)$ and $\mathrm{KC}$ in female subjects.

Table 3 illustrates the associations of COL4A4 (rs2228557) and TIMP-1 (rs4898) with KC severity. This polymorphism TIMP1 (rs4898 T/C) located at $\mathrm{X}$ chromosome exists in two alleles and their combination results in five possible genotypes. Because men lack a second X-chromosome, the possible genotypes are $C Y$ and TY hemizygotes $(Y$ states for the $Y$-chromosome). As for women, there are CC and TT homozygotes and CT heterozygotes (Table 2). In fact, men just have allele and women have genotype and allele. For this reasons, calculation of TIMP1 (rs4898) distinctly separated in men and women was done. So, results in men and women can be different.

\section{DISCUSSION}

Keratoconus is an eye disorder characterized by bilateral, asymmetrical, noninflammatory, and progressive thinning of the cornea. The shape of cornea progressively alters from the normal round shape to a cone shaped one. Although the etiology of $\mathrm{KC}$ is not clear, defective cross-linking between adjacent collagen fibers may play an important role in its pathogenesis. ${ }^{[41]}$ SNPs and gene variants suggest an intricate etiology or the convergence of multiple disease pathways. ${ }^{[42]}$

Biochemical investigations have suggested that the amount of collagen fibers decrease in KC. Also, the weight of $\mathrm{KC}$ corneas was found to be reduced; 
therefore, it can be assumed that collagenase enzymes might be involved. ${ }^{[43]}$

In the current study, we investigated the impact of COL4A4 and TIMP-1 variants on the risk of $\mathrm{KC}$ development in a sample of Iranian population. Our results showed that the $T$ allele reduced the risk of disease development, as compared to the $\mathrm{C}$ allele. Results in the distribution of genotypes (CC, CT, TT) in rs2228557 of the COL4A4 gene between $\mathrm{KC}$ patients and controls in the Stabuc-Silih et al's study were different from our results. ${ }^{[14]}$ Similar to our findings, Kokolakis et al demonstrated that the TT genotype was significantly over-represented in healthy individuals and suggested a protective role for this genotype in the KC development. ${ }^{[31]}$

The level of TIMP-1 significantly decreases in $\mathrm{KC}$ as compared to normal corneas. Given the fact that $K C$ is not associated with extensive scarring or inflammatory infiltrates, substantial degradation should occur in the extracellular matrix. A decreased level of TIMP-1 increases gelatinase and collagenase activities and apoptosis which are characteristic phenomena in $\mathrm{KC}$. Decreases in TIMP-1 might play a role in matrix degradation which is a characteristic feature of KC. ${ }^{[15,44]}$ Furthermore, it has been recognized that increased MMP and decreased TIMP-1 levels are associated with the development of KC. ${ }^{[29]}$

The TIMP-1 gene is located in Xp11.3-p11.23 and has three types of polymorphism including TIMP$1(19 \mathrm{C} / \mathrm{T})$ in the 5'-UTR, TIMP-1 (261 C/T) in exon 4, and TIMP-1 (372 T/C) (rs4898) in exon 5. The TIMP-1 (rs4898) polymorphism is an important site which has been reported in other studies. This variation does not result in changes in the amino acid sequence (F124F). This polymorphism exists in two alleles and their combination results in five possible genotypes. Because male subjects lack a second $\mathrm{X}$-chromosome, the possible genotypes are $\mathrm{CY}$ and TY hemizygotes. In female subjects, however, there are CC and TT homozygotes and CT heterozygote genotypes. ${ }^{[40]}$

Our data suggest that $\mathrm{C}$ or $\mathrm{T}$ allele is associated with TIMP-1 (rs4898) polymorphism in patients or controls. The $\mathrm{C}$ allele of the $372 \mathrm{~T} / \mathrm{C}$ polymorphism was more frequently found in female than male controls. ${ }^{[45]}$ However, in other studies, the C allele was detected more frequently in male patients with an abdominal aortic aneurysm. ${ }^{[46]}$ Meijer et al investigated the male subjects with inflammatory bowel disease carrying TIMP-1 (rs4898) $\mathrm{T}$ allele. They reported lower levels of TIMP-1 in surgically resected inflamed tissue, as compared to $C$ allele carriers. ${ }^{[47]}$ In addition, Indelicato et al reported that TIMP-1 (rs4898) $C$ allele frequency increased in males but not females with systemic sclerosis, as compared to healthy individuals. ${ }^{[48]}$ Along the same lines, Wei et al revealed that $C$ allele carriers of TIMP-1 (rs4898) run a greater risk of developing ankylosing spondylitis disease. ${ }^{[4]}$ Furthermore, it was found that among cirrhotic patients, males with TIMP-1 $(372 \mathrm{C} / \mathrm{T}) \mathrm{T}$ allele developed cirrhosis at a younger age. ${ }^{[50]}$

Our findings indicated that TIMP-1 (rs4898) was associated with the clinical characteristics of $\mathrm{KC}$ only in our male sample population. Nevertheless, the analysis of genotype and allele frequencies revealed no significant differences in female patients as compared to female controls. The $T$ allele decreased the risk of $\mathrm{KC}$, as compared to the $C$ allele in males which can be attributed to the location of TIMP-1 gene at Xp11.3-p11.23. Males only have one $\mathrm{X}$-chromosome, and the functional difference of genetic polymorphism of TIMP1 (rs4898) appears more obvious due to the lack of heterozygotes. We cannot compare our results with the literature because no previous study has evaluated the correlation between the TIMP-1 variants and the risk of $\mathrm{KC}$ development.

In conclusion, our study showed that in the COL4A4 rs2228557 C/T variant, the $\mathrm{T}$ allele acts as a protective factor against the disease and decreases the risk of KC. In addition, TIMP-1 rs4898 $\mathrm{C} / \mathrm{T}$ the $\mathrm{TY}$ genotype or $\mathrm{T}$ allele in males can decrease the risk of $\mathrm{KC}$ in comparison with the $\mathrm{C}$ allele. Further studies with a larger sample size and different ethnicities are required to confirm these findings.

\section{Financial Support and Sponsorship}

This study was supported by a dissertation grant (M.Sc. thesis of Davood Yari, NO. 6077) from the Deputy for Research, Zahedan University of Medical Sciences.

\section{Conflicts of Interests}

There are no conflicts of interest. 


\section{REFERENCES}

1. Burdon $\mathrm{KP}$, Vincent $\mathrm{AL}$. Insights into keratoconus from a genetic perspective. Clin Exp Optom 2013;96:146-154.

2. Gajecka M, Radhakrishna U, Winters D, Nath SK, Rydzanicz M, Ratnamala $U$, et al. Localization of a gene for keratoconus to a 5.6-Mb interval on $13 q 32$. Invest Ophthalmol Vis Sci 2009;50:1531-1539.

3. Lee LR, Hirst LW, Readshaw G. Clinical detection of unilateral keratoconus. Aust $N Z J$ Ophthalmol 1995;23:129-133.

4. Li X, Bykhovskaya Y, Canedo AL, Haritunians T, Siscovick $D$, Aldave AJ, et al. Genetic association of COL5A1 variants in keratoconus patients suggests a complex connection between corneal thinning and keratoconus. Invest Ophthalmol Vis Sci 2013;54:2696-2704.

5. Grewal DS, Brar GS, Grewal SP. Assessment of central corneal thickness in normal, keratoconus, and postlaser in situ keratomileusis eyes using Scheimpflug imaging, spectral domain optical coherence tomography, and ultrasound pachymetry. J Cataract Refract Surg 2010;36:954-964.

6. Rabinowitz YS. Keratoconus. Surv Ophthalmol 1998;42:297-319.

7. Pearson AR, Soneji B, Sarvananthan N, Sandford-Smith JH. Does ethnic origin influence the incidence or severity of keratoconus? Eye 2000;14:625-628.

8. Sahebjada S, Schache M, Richardson AJ, Snibson G, MacGregor S, Daniell M, et al. Evaluating the association between keratoconus and the corneal thickness genes in an independent Australian population. Invest Ophthalmol Vis Sci 2013;54:8224-8228.

9. Bae HA, Mills RA, Lindsay RG, Phillips T, Coster DJ, Mitchell $P$, et al. Replication and meta-analysis of candidate loci identified variation at RAB3GAP1 associated with keratoconus. Invest Ophthalmol Vis Sci 2013;54:51325135.

10. Hasanian-Langroudi F, Saravani R, Validad MH, Bahari G, Yari D. Association of Lysyl oxidase (LOX) polymorphisms with the risk of Keratoconus in an Iranian population. Ophthalmic Genet 2014;0:1-6.

11. Heon E, Greenberg A, Kopp KK, Rootman D, Vincent $A L$, Billingsley $G$, et al. VSX1: a gene for posterior polymorphous dystrophy and keratoconus. Hum Mol Genet 2002;11:1029-1036.

12. Yari D, Saravani R, Saravani S, Ebrahimian K, Galavi HR. Genetic polymorphisms of catalase and glutathione peroxidase-1 in keratoconus. Iran $J$ Public Health 2018;47:1567-1574.

13. Guan T, Liu C, Ma Z, Ding S. The point mutation and polymorphism in keratoconus candidate gene TGFBI in Chinese population. Gene 2012;503:137-139.

14. Stabuc-Silih M, Ravnik-Glavac M, Glavac D, Hawlina $M$, Strazisar M. Polymorphisms in COL4A3 and COL4A4 genes associated with keratoconus. Mol Vis 2009;15:2848-2860.

15. Lee JE, Oum BS, Choi HY, Lee SU, Lee JS. Evaluation of differentially expressed genes identified in keratoconus. Mol Vis 2009;15:2480-2487.

16. Fullerton J, Paprocki P, Foote S, Mackey DA, Williamson $\mathrm{R}$, Forrest $\mathrm{S}$. Identity-by-descent approach to gene localisation in eight individuals affected by keratoconus from north-west Tasmania, Australia. Hum Genet 2002;110:462-470.

17. Patel D, McGhee C. Understanding keratoconus: what have we learned from the New Zealand perspective? Clin Exp Optom 2013;96:183-187.

18. Boye E, Mollet G, Forestier L, Cohen-Solal L, Heidet L, Cochat $P$, et al. Determination of the genomic structure of the COL4A4 gene and of novel mutations causing autosomal recessive Alport syndrome. Am J Hum Genet 1998;63:1329-1340.

19. Mariyama M, Zheng K, Yang-Feng TL, Reeders ST. Colocalization of the genes for the alpha 3(IV) and alpha 4(IV) chains of type IV collagen to chromosome 2 bands q35-q37. Genomics 1992;13:809-813.

20. Stachs O, Bochert A, Gerber T, Koczan D, Thiessen HJ, Guthoff RF. [The extracellular matrix structure in keratoconus]. Ophthalmologe 2004;101:384-389.

21. Bochert A, Berlau J, Koczan D, Seitz B, Thiessen HJ, Guthoff R. [Gene expression in keratoconus. Initial results using DNA microarrays]. Ophthalmologe 2003;100:545549.

22. Nielsen K, Hjortdal J, Pihlmann M, Corydon TJ. Update on the keratoconus genetics. Acta Ophthalmol 2013;91:106113.

23. Brew K, Dinakarpandian D, Nagase H. Tissue inhibitors of metalloproteinases: evolution, structure and function. Biochim Biophys Acta 2000;1477:267-283.

24. Brew K, Nagase $H$. The tissue inhibitors of metalloproteinases (TIMPS): an ancient family with structural and functional diversity. Biochim Biophys Acta 2010;1803:55-71.

25. Guedez L, Stetler-Stevenson WG, Wolff L, Wang J, Fukushima P, Mansoor A, et al. In vitro suppression of programmed cell death of $B$ cells by tissue inhibitor of metalloproteinases-1. J Clin Invest 1998;102:2002-2010.

26. Usher PA, Sieuwerts AM, Bartels A, Lademann U, Nielsen $\mathrm{HJ}$, Holten-Andersen L, et al. Identification of alternatively spliced TIMP-1 mRNA in cancer cell lines and colon cancer tissue. Mol Oncol 2007;1:205-215.

27. Akahane T, Akahane M, Shah A, Connor CM, Thorgeirsson UP. TIMP-1 inhibits microvascular endothelial cell migration by MMP-dependent and MMP-independent mechanisms. Exp Cell Res 2004;301:158-167.

28. Johnson MD, Kim HR, Chesler L, Tsao-Wu G, Bouck N, Polverini PJ. Inhibition of angiogenesis by tissue inhibitor of metalloproteinase. J Cell Physiol 1994;160:194-202.

29. Brown D, Chwa MM, Opbroek A, Kenney MC. Keratoconus corneas: increased gelatinolytic activity appears after modification of inhibitors. Curr Eye Res 1993;12:571-581.

30. Saravani R, Hasanian-Langroudi F, Validad MH, Yari D, Bahari G, Faramarzi M, et al. Evaluation of possible relationship between COL4A4 gene polymorphisms and risk of keratoconus. Cornea 2015;34:318-322.

31. Kokolakis NS, Gazouli M, Chatziralli IP, Koutsandrea C, Gatzioufas Z, Peponis VG, et al. Polymorphism analysis of COL4A3 and COL4A4 genes in Greek patients with keratoconus. Ophthalmic Genet 2014;35:226-228.

32. Wang HX, Yang QD, Liu BQ, Zhang L, Ma MM, Hu ZY, et al. TIMP-1 polymorphisms in a Chinese Han population with intracerebral hemorrhage. Int J Neurosci 2014;124:61-67. 
33. Skarmoutsou E, D’Amico F, Marchini M, Malaponte G, Scorza R, Mazzarino MC. Association of TIMP-1 +372 SNP with digital ulcer manifestation in female systemic sclerosis patients. Hum Immunol 2012;73:950-953.

34. Lorente L, Martin M, Plasencia F, Sole-Violan J, Blanquer J, Labarta L, et al. The 372 T/C genetic polymorphism of TIMP-1 is associated with serum levels of TIMP-1 and survival in patients with severe sepsis. Crit Care 2013;17:R94.

35. Mikami T, Meguro A, Teshigawara T, Takeuchi M, Uemoto R, Kawagoe T, et al. Interleukin 1 beta promoter polymorphism is associated with keratoconus in a Japanese population. Mol Vis 2013;19:845-851.

36. Hashemi M, Amininia S, Ebrahimi M, Hashemi SM, Yousefi J, Eskandari-Nasab E, et al. Association between LAPTM4B gene polymorphism and breast cancer susceptibility in an Iranian population. Med Oncol 2014;31:111.

37. Haff LA. Improved quantitative PCR using nested primers. PCR Methods App/ 1994;3:332-337.

38. Newton CR, Graham A, Heptinstall LE, Powell SJ, Summers $\mathrm{C}$, Kalsheker $\mathrm{N}$, et al. Analysis of any point mutation in DNA. The amplification refractory mutation system (ARMS). Nucleic Acids Res 1989;17:2503-2516.

39. Dai S, Long Y. Genotyping Analysis Using an RFLP Assay. Methods Mol Biol 2015;1245:91-99.

40. Naychov ZD, Hiyama E, Uchida N, Arihiro K, Nagao M, Takahashi S, et al. TIMP-1 c.T372C Genetic Polymorphism as a Possible Predictor for Acute Aortic Dissection. Hiroshima J Med Sci 2013;62:31-37.

41. Ormonde S. Refractive surgery for keratoconus. Clin Exp Optom 2013;96:173-182.

42. Crawford A, Fassett RG, Geraghty DP, Kunde DA, Ball $\mathrm{MJ}$, Robertson IK, et al. Relationships between single nucleotide polymorphisms of antioxidant enzymes and disease. Gene 2012;501:89-103.

43. Collier SA. Is the corneal degradation in keratoconus caused by matrix-metalloproteinases? Clin Experiment Ophthalmol 2001;29:340-34.
44. Kenney MC, Chwa M, Atilano SR, Tran A, Carballo M, Saghizadeh $M$, et al. Increased levels of catalase and cathepsin V/L2 but decreased TIMP-1 in keratoconus corneas: evidence that oxidative stress plays a role in this disorder. Invest Ophthalmol Vis Sci 2005;46:823-832.

45. Krex D, Rohl H, Konig IR, Ziegler A, Schackert HK, Schackert $\mathrm{G}$. Tissue inhibitor of metalloproteinases-1, 2 , and -3 polymorphisms in a white population with intracranial aneurysms. Stroke 2003;34:2817-2821.

46. Hinterseher I, Krex D, Kuhlisch E, Schmidt KG, Pilarsky C, Schneiders W, et al. Tissue inhibitor of metalloproteinase1 (TIMP-1) polymorphisms in a Caucasian population with abdominal aortic aneurysm. World J Surg 2007;31:22482254.

47. Meijer MJ, Mieremet-Ooms MA, van Hogezand RA, Lamers CB, Hommes DW, Verspaget HW. Role of matrix metalloproteinase, tissue inhibitor of metalloproteinase and tumor necrosis factor-alpha single nucleotide gene polymorphisms in inflammatory bowel disease. World $\mathrm{J}$ Gastroenterol 2007;13:2960-2966.

48. Indelicato M, Chiarenza V, Libra M, Malaponte G, Bevelacqua V, Marchini M, et al. Analysis of TIMP-1 gene polymorphisms in Italian sclerodermic patients. J Clin Lab Anal 2006;20:173-176.

49. Wei JC, Lee HS, Chen WC, Shiu LJ, Yang SF, Wong RH. Genetic polymorphisms of the matrix metalloproteinase-3 (MMP-3) and tissue inhibitors of matrix metalloproteinases1 (TIMP-1) modulate the development of ankylosing spondylitis. Ann Rheum Dis 2009;68:1781-1786.

50. Ikebuchi Y, Ishida C, Okamoto K, Murawaki Y. Association of TIMP-1 and TIMP-2 gene polymorphisms with progression of liver fibrosis in patients with type $C$ chronic liver disease. Biochem Genet 2013;51:564-574.

51. Saravani R, Yari D, Saravani S, Hasanian-Langroudi F. Correlation between the COL4A3, MMP-9, and TIMP-1 polymorphisms and risk of keratoconus. Jpn J Ophthalmol 2017;61:218-222. 